\title{
Isolation and characterization of Ni mobilizing PGPB from serpentine soils and their potential in promoting plant growth and $\mathrm{Ni}$ accumulation by Brassica spp.
}

\author{
Ying Ma*, Mani Rajkumar, Helena Freitas \\ Centre for Functional Ecology, Department of Botany, University of Coimbra, Coimbra 3000, Portugal
}

\section{A R T I C L E I N F O}

\section{Article history:}

Received 5 December 2008

Received in revised form 20 January 2009

Accepted 20 January 2009

Available online $\mathrm{xxxx}$

\section{Keywords:}

Phytoextraction

Brassica juncea

Ni mobilizing bacteria

Rhizosphere

ACC deaminase

\begin{abstract}
A B S T R A C T
The study was undertaken to assess the effects of Ni mobilizing bacteria on the plant growth and the uptake of Ni by Brassica juncea and Brassica oxyrrhina. Among a collection of Ni resistant bacterial strains isolated from the non-rhizosphere and rhizosphere soils of Alyssum serpyllifolium and Astragalus incanus at a serpentine site in Bragança, north-east of Portugal, nine strains were selected based on their ability to solubilize Ni in soil. Further assessment on plant growth-promoting parameters revealed the intrinsic ability of the Ni mobilizing strains to produce indole-3-acetic acid (IAA), siderophores, utilize 1-aminocyclopropane-1-carboxylic acid (ACC) as the sole $\mathrm{N}$ source and solubilize insoluble phosphate. All of the strains tested positive for IAA production and phosphate solubilization. In addition, all the strains, except SRS5 exhibited significant levels of siderophore production. Besides, five isolates showed positive for ACC deaminase activity. In pot experiments, inoculation of plants with Ni mobilizing strains increased the biomass of both B. juncea and B. oxyrrhina. Among the strains, Pseudomonas sp. SRI2, Psychrobacter sp. SRS8 and Bacillus sp. SN9 showed maximum increase in the biomass of the test plants. In addition, the strain SN9 significantly increased the Ni concentration in the root and shoot tissues of B. juncea and $B$. oxyrrhina. Further, a significantly positive correlation was observed between the bacterial Ni mobilization in soil and the total Ni uptake in both plant species. The findings, therefore, revealed that inoculation of $\mathrm{Ni}$ mobilizing plant growth-promoting bacterial strain SN9 increases the efficiency of phytoextraction directly by enhancing $\mathrm{Ni}$ accumulation in plant tissues and indirectly by promoting the shoot and root biomass of $B$. juncea and $B$. oxyrrhina.
\end{abstract}

(c) 2009 Elsevier Ltd. All rights reserved.

\section{Introduction}

The contamination of soils with metals especially Ni is a major environmental problem throughout the world. Soils polluted with $\mathrm{Ni}$ may threaten ecosystems and human health. The remediation of soils contaminated with metals is a challenging task because metals cannot be degraded and the danger they pose is aggravated by their almost indefinite persistence in the environment. Conventional cleanup technologies are generally too costly to be used to restore contaminated sites, and are often harmful to the normal properties of the soil (i.e., texture and organic matter) (Holden, 1989). The emerging phytoremediation techniques, with their lower cost and environmental friendly nature, have received increasing attention in the last decades (Kumar et al., 1995).

The success of the phytoremediation process, whereby metals are effectively removed from soil, is dependent on an adequate yield of plants and on the efficient transfer of metals from the roots of the plants into their shoots. Most hyperaccumulators, such as Thlaspi, Urtica, Chenopodium, Polygonum sachalase and Alyssum

\footnotetext{
* Corresponding author. Tel.: +351 239 855243; fax: +351 239855211

E-mail address: cathymaying@yahoo.com.cn (Y. Ma).
}

are characterized by slow growth and low-biomass production, which make these plants impractical for use in phytoextraction in the field (Puschenreiter et al., 2001). Hence, recent research projects on phytoextraction have focused on high-biomass crop species, such as maize, peas, oats and Indian mustard, and on relevant plant husbandry and soil management practices to enhance the metal uptake of these high-biomass species (Chen et al., 2004). Although several conditions must be met in order for phytoremediation to be effective, the bioavailability of metals to plant roots is considered to be a critical requirement for plant uptake to occur (Kayser et al., 2000). Soil factors such as pH, cation exchange capacity, or organic matter content play an important role in successful soil remediation processes. In recent years, several synthetic chelators such as EDTA have been suggested to enhance phytoextraction efficiency in metal-contaminated soils (Puschenreiter et al., 2001). However, chelator application in chemically assisted phytoextraction may also have potentially environmental risks. For instance, some chelators themselves are usually phytotoxic, and increasing metal solubility by them may be also phytotoxic to non-hyperaccumulator plants, thus plant growth may be inhibited, and the chance of success with chemically assisted phytoextraction may be lowered (McGrath and Zhao, 
2003). Therefore, the potential use of alternative methods that exploit rhizosphere microbes to enhance phytoextraction potential of hyperaccumulating plants has been investigated (Abou-Shanab et al., 2003; Pal et al., 2005). The metal resistant microbes in rhizosphere can affect trace metal mobility and availability to the plants through release of chelating agents, acidification, phosphate solubilization and redox changes (Abou-Shanab et al., 2003; Idris et al., 2004). For example, chemolithotrophic bacteria have been shown to enhance environmental mobility of metal contaminants via soil acidification, or in contrast, to decrease their solubility due to precipitation as sulfides. In addition, the naturally occurring bacteria in soils, contaminated with nickel have acquired resistance against nickel and other metals (Pal et al., 2005). Furthermore, these metal resistant bacteria have exceptional ability to promote the growth of the host plant by various mechanisms, namely fixation of atmospheric nitrogen, production of siderophores, solubilization of phosphate, or production of plant growth regulators (hormones) (Glick et al., 1998; Abou-Shanab et al., 2005). Therefore, such organisms endowed with $\mathrm{Ni}$ mobilizing ability and plant growth-promoting activities are of practical importance for efficient phytoremediation of metal-contaminated environment.

The objectives of this study were to isolate and characterize $\mathrm{Ni}$ resistant bacteria from $\mathrm{Ni}$ rich serpentine soils, and to select $\mathrm{Ni}$ mobilizing plant growth-promoting bacterial (PGPB) strains which might be useful to increase the plant $\mathrm{Ni}$ uptake and biomass production under unfavourable environmental conditions for improving the efficiency of phytoremediation of Ni-polluted soils.

\section{Materials and methods}

\subsection{Experimental plant}

Two Brassica sp., B. juncea and B. oxyrrhina were selected for this study based on their demonstrated ability to accumulate substantial amounts of metals in shoots (Kumar et al., 1995) and to produce substantial biomass in a very short time.

\subsection{Isolation of Ni mobilizing bacteria}

The bacterial strains were isolated from the non-rhizosphere and rhizosphere soils of Alyssum serpyllifolium and Astragalus incanus in serpentine soil at Bragança, north-east of Portugal, previously described by Freitas et al. (2004). Briefly, plants were harvested and their roots were shaken to remove the loosely attached soil. Soil adhering to the root was considered as the rhizosphere soil. The soil sample collected from unplanted serpentine area was considered as the non-rhizosphere soil. About $1 \mathrm{~g}$ of soil samples were serially diluted using $25 \mathrm{mM}$ phosphate buffer and spread over on Luria-Bartani medium (LB) amended with $50 \mathrm{mg}$ of $\mathrm{Ni} \mathrm{L}^{-1}\left(\mathrm{NiCl}_{2}\right)$. The plates were incubated at $37^{\circ} \mathrm{C}$ for $48 \mathrm{~h}$. From the $\mathrm{Ni}$ resistant colonies, different strains were picked and purified on the LB medium containing $50 \mathrm{mg} \mathrm{L}^{-1}$ of $\mathrm{Ni}$ according to the procedure of Rajkumar and Freitas (2008).

In order to isolate the $\mathrm{Ni}$ mobilizing bacteria, the $\mathrm{Ni}$ resistant strains were tested for the ability to increase the water soluble $\mathrm{Ni}$ concentrations in artificially $\mathrm{Ni}$ contaminated soils. The soil was collected from the Botanical garden, Department of Botany, University of Coimbra, Coimbra, Portugal. The soil was sieved $(2 \mathrm{~mm})$ and sterilized by steaming $\left(100^{\circ} \mathrm{C}\right.$ for $1 \mathrm{~h}$ on three consecutive days). After sterilization the soil was amended with aqueous solution of $\mathrm{NiCl}_{2}$ to achieve the final nickel concentrations of $450 \mathrm{mg} \mathrm{Ni} \mathrm{kg}^{-1}$ and left in a greenhouse for a 2-week period (for metal stabilization). The Ni resistant strains were grown in LB broth and placed on a shaker at $200 \mathrm{rpm}$ and $27^{\circ} \mathrm{C}$. After $24 \mathrm{~h}$, opti- cal density $(600 \mathrm{~nm})$ was measured and adjusted to 1.5 ; the cultures were centrifuged at $6000 \mathrm{rpm}$ for $10 \mathrm{~min}$, washed in phosphate buffer ( $\mathrm{pH}$ 7.0) twice, resuspended, washed in sterile water twice, resuspended. Small aliquots of washed bacterial culture (up to $1 \mathrm{~mL}$ ) were added to the $1 \mathrm{~g}$ of soil in the centrifuge tubes. Sterile water was added to soil as an axenic control. All tubes were placed on an orbital shaker at $200 \mathrm{rpm}$ at $27^{\circ} \mathrm{C}$. After $5 \mathrm{~d}$, $10 \mathrm{~mL}$ of sterile water were added to each tube to extract the soil water soluble $\mathrm{Ni}$. The soil suspensions were centrifuged at $7000 \mathrm{rpm}$ for $10 \mathrm{~min}$ and filtered. The concentrations of $\mathrm{Ni}$ in the filtrate were determined by atomic absorption spectrophotometer.

\subsection{Genetic characterization of Ni mobilizing bacterial stains}

The bacterial strains were grown in LB broth in presence of $1 \mathrm{mM} \mathrm{Ni}$ at $30^{\circ} \mathrm{C}$. Cells were harvested after $20 \mathrm{~h}$ and processed immediately for DNA isolation using standard procedure (Sambrook et al., 1989). Amplification of 16S rRNA gene sequence was performed by polymerase chain reaction (PCR) with the conserved eubacterial primers pA (5'-AGAGTTTGATCCTGGCTCAG; Escherichia coli bases 8-27) and pC5B (5'-TACCTTGTTACGACTT; E. coli bases 1507-1492) (Dunbar et al., 1999). Reaction conditions were as described by Branco et al. (2005). Each amplification mixture $(5 \mu \mathrm{L})$ was analyzed by agarose gel $(1.5 \% \mathrm{w} / \mathrm{v})$ electrophoresis in TAE buffer $\left(0.04 \mathrm{M}\right.$ Tris acetate, $0.001 \mathrm{M}$ EDTA) containing $1 \mu \mathrm{g} \mathrm{mL} \mathrm{L}^{-1}(\mathrm{w} / \mathrm{v})$ ethidium bromide. For further sequencing reaction, the amplified DNA was purified from salts and primers using the PCR purification kit (Roche Diagnostics) according to the manufacturer's instructions. Automated sequencing of the purified PCR products was performed using the dRodamina terminator cycle sequencing kit and the ABI 310 DNA Sequencer (Applied Biosystems, Foster City, CA) according to the manufacturer's instructions. Partial 16S rDNA sequences obtained were matched against nucleotide sequences present in GenBank using the BLASTn program (Altschul et al., 1997).

\subsection{Plant growth-promoting features of Ni mobilizing bacteria}

The 1-aminocyclopropane-1-carboxylic acid (ACC) deaminase activity of cell-free extracts was determined by estimating the amount of $\alpha$-ketobutyrate $(\alpha-K B)$ generated by the enzymatic hydrolysis of ACC according to the procedure of Honma and Shimomura (1978).

Indole-3-acetic acid (IAA) production by Ni mobilizing bacteria was determined according to the method of Bric et al. (1991). Cultures of the isolates were raised in LB broth amended with $500 \mu \mathrm{g} \mathrm{mL}{ }^{-1}$ of tryptophan at $27^{\circ} \mathrm{C}$ for $120 \mathrm{~h}$ at $200 \mathrm{rpm}$. Cells were removed by centrifugation at $6000 \mathrm{rpm}$ and the supernatant was assayed for IAA production.

$\mathrm{Ni}$ mobilizing bacteria were screened for the production of siderophores by the method of Schwyn and Neilands (1987) using chrome azurol S (CAS) agar. Briefly, the assay was performed by spotting $50 \mu \mathrm{L}$ of each exponential bacterial culture previously grown under iron-restricted conditions in casamino acids (CAA) medium onto CAS agar. The siderophore levels produced by the isolates were recorded as the diameter of the orange halo produced by the colony. The presence of catechol and hydroxamate siderophores in culture supernatants obtained from bacteria grown either in iron-restricted conditions in CAA medium was quantitatively determined by the colorimetric assay of Arnow (1937), using 2,3-dihydroxybenzoic acid and the Atkin et al. (1970) method, using desferrioxamine mesylate as standards, respectively.

The phosphate solubilizing activity of the isolates was analyzed in modified Pikovskayas medium (Sundara-Rao and Sinha, 1963) amended with $0.5 \%$ of tricalcium phosphate. The isolates were grown at $27^{\circ} \mathrm{C}$ for $120 \mathrm{~h}$ at $200 \mathrm{rpm}$. The solubilized phosphate 
in the culture supernatant was quantified as detailed by Fiske and Subbarow (1925).

\subsection{Influence of Ni mobilizing PGPB on plant growth and Ni uptake}

For pot experiments the soil collected from botanical garden was amended with aqueous solution of $\mathrm{NiCl}_{2}$ to achieve the final $\mathrm{Ni}$ concentrations of $450 \mathrm{mg} \mathrm{kg}^{-1}$ as detailed in the earlier section. Before inoculation, the mutant of Ni mobilizing PGPB marked with antibiotic resistance were obtained after plating of the parental strain onto LB agar amended with ampicillin $\left(75 \mathrm{mg} \mathrm{L}^{-1}\right)$. The seeds of $B$. juncea and $B$. oxyrrhina were inoculated by soaking in a bacterial suspension after adjusting $\mathrm{OD}_{600 \mathrm{~nm}}$ to 1 for $2 \mathrm{~h}$. Seeds soaked in sterile water were used as control. The inoculated and non-inoculated seeds were planted in plastic pot (top diameter $120 \mathrm{~mm}$, bottom $100 \mathrm{~mm}$ and height $90 \mathrm{~mm}$ ) containing $300 \mathrm{~g}$ of soil. The plants were grown in a glasshouse at $25^{\circ} \mathrm{C}$ and a $16 /$ $8 \mathrm{~d} /$ night regime. After $45 \mathrm{~d}$ the plants were carefully removed from the pots and the root surface was cleaned several times with distilled water. Growth parameters such as fresh weight and dry weight of the plants were measured. The accumulation of $\mathrm{Ni}$ in root and shoot system was also quantified following the method of Freitas et al. (2004). In addition, the population dynamics of introduced bacteria was studied using the intrinsic antibiotic marker. The adhering soil was removed from plant roots. For determination of rhizosphere soil colonization, $0.5 \mathrm{~g}$ soil removed from the roots was shaken with $10 \mathrm{~mL}$ sterile water for $30 \mathrm{~min}$. The resulting suspensions were evaluated for colony forming units (cfu) according to the dilution-plate method on LB agar with addition of $75 \mathrm{mg} \mathrm{L}^{-1}$ ampicillin. The plates were incubated for $4 \mathrm{~d}$ at $28^{\circ} \mathrm{C}$. By adding ampicillin, the native bacterial flora was mostly excluded from the plates.

\subsection{Statistical analysis}

Analysis of variance followed by post-hoc Fisher LSD test $(p<0.05)$ were used to compare treatment means. Simple regression analysis was used to compare relationships between bacterial $\mathrm{Ni}$ mobilization in soil and Ni uptake in two plant species inoculated with bacterial isolates. All the statistical analyses were carried out using SPSS 10.0.

\section{Results and discussion}

\subsection{Isolation and characterization of Ni mobilizing bacteria}

Serpentine or ultramafic soils are produced by weathering and pedogenesis of ultramafic rocks that are characterized by high levels of $\mathrm{Ni}, \mathrm{Cr}$ and sometimes $\mathrm{Co}$, but contain low levels of essential nutrients such as N, P, K and Ca (Brooks, 1987). Numbers of plant species such as A. serpyllifolium, Bromus hordeaceus, Linaria spartea etc. endemic to serpentine soils are capable of accumulating exceptionally high concentrations of Ni (Freitas et al., 2004). However, the function of hyperaccumulation not only depends on the plant, but also on the interaction of the plant roots with rhizosphere microbes and the concentrations of bioavailable metals in soil. Currently, microorganisms present in serpentine soil and their interaction with serpentinophytes have attracted the attention of several investigators due to biotechnological applications for microbial-assisted phytoremediation (Abou-Shanab et al., 2005; Pal et al., 2005). Bacterial communities in serpentine soil were reported to tolerate spiking of metals, such as nickel, lead, copper and zinc (Abou-Shanab et al., 2005). Also, evidence was presented that the rhizosphere of hyperaccumulating plants, such as Thlaspi goesingense and $A$. murale has an increased proportion of metal resistant bacteria (Abou-Shanab et al., 2003; Idris et al., 2004). Furthermore, the serpentine bacteria have been shown to possess several traits that can alter heavy metal mobility and availability to the plants (Rajkumar and Freitas, 2008). Hence, in this investigation we isolated $\mathrm{Ni}$ mobilizing bacteria from a $\mathrm{Ni}$ rich serpentine environment and assessed their efficiency in promoting plant growth and Ni uptake in Brassica species. During the initial screening, $23 \mathrm{Ni}\left(50 \mathrm{mg} \mathrm{L}^{-1}\right)$ resistant bacterial strains were isolated from the soil samples. In order to isolate the Ni mobilizing bacteria, the $\mathrm{Ni}$ resistant strains were tested for the ability to increase the water soluble Ni concentrations in soils. Among the 23 strains tested, nine strains namely SN3, SN9, SRS5, SRS8, SRS15, SRI2, SRI4, SRI11 and SRI14 significantly increased the concentrations of water soluble $\mathrm{Ni}$ in soil compared with non-inoculated control (Fig. 1). In general the soil bacteria have been known to exude biosurfactants, organic acids and to produce siderophores which stimulate metal bioavailability in soil and thereby facilitate their uptake through root absorption of various metal ions, including $\mathrm{Fe}^{2+}$ (Crowley et al., 1991), $\mathrm{Mn}^{2+}$ (Barber and Lee, 1974) and possibly $\mathrm{Cd}^{2+}$ (Salt et al., 1995). Enhanced Ni bioavailability by bioaugmentation of bacterial inocula (Microbacterium arabinogalactanolyticum) has been also reported by Abou-Shanab et al. (2003) from serpentine soils.

The Ni mobilizing strains exhibited a high tolerance to Ni when cultivated under increasing Ni levels in the growth medium (Table 1). Extremely high $\mathrm{Ni}$ resistance (up to the concentration of $1250 \mathrm{mg} \mathrm{L}^{-1}$ ) was observed for the strains SRS5 followed by stains SN9, SRS8 and SRS15 (1000 $\left.\mathrm{mg} \mathrm{L}^{-1} \mathrm{Ni}\right)$, whereas strain SN3 showed relatively low tolerance to $\mathrm{Ni}\left(500 \mathrm{mg} \mathrm{L}^{-1}\right)$. This high tolerance to $\mathrm{Ni}$ could be attributed to the fact that the bacteria were isolated from a serpentine soil containing high levels of Ni (Freitas et al., 2004). Microorganisms isolated from natural environments contaminated with heavy metals often exhibit tolerance to multiple

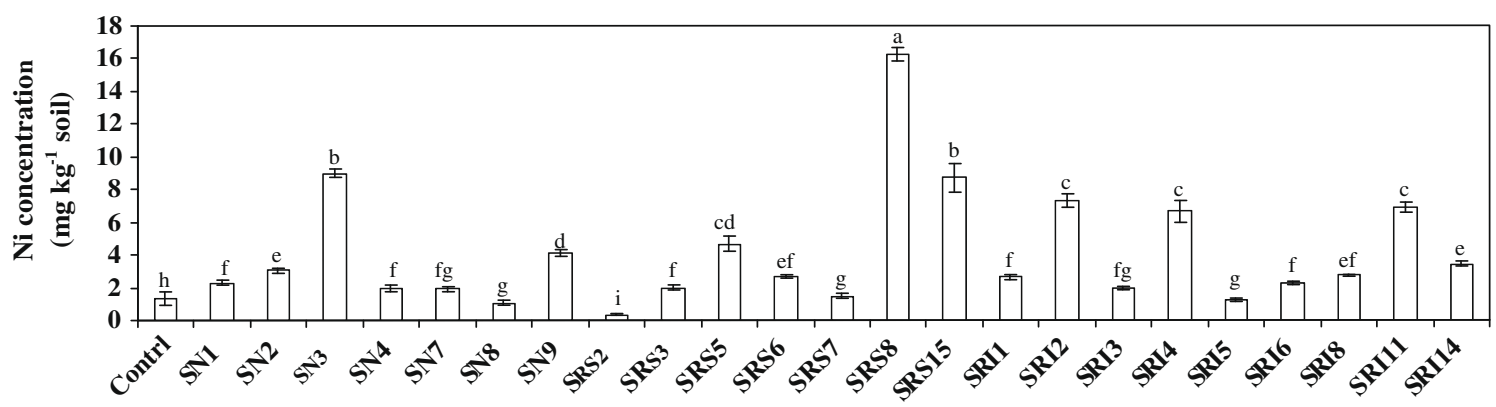

Ni resistant bacterial strains

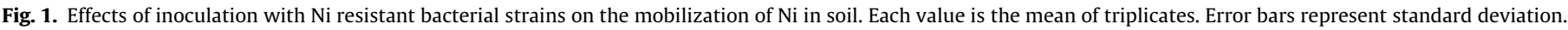
Data of columns indexed by the same letter are not significantly different according to Fisher's protected LSD test ( $p<0.05)$. 
Table 1

Bacterial strains used in this study.

\begin{tabular}{|c|c|c|c|c|c|c|}
\hline Strain & Closest described relative & Accession no. & bp & Similarity (\%) & Origin & Ni tolerance level $\left(\mathrm{mg} \mathrm{L}^{-1}\right)$ \\
\hline SN3 & Bacillus sp. & FM205065 & 858 & 100 & Non-rhizosphere serpentine soil & 500 \\
\hline SN9 & Bacillus sp. & FM205066 & 800 & 99 & Non-rhizosphere serpentine soil & 1000 \\
\hline SRS5 & Bacillus sp. & FM205058 & 549 & 98 & Rhizosphere of Alyssum serpyllifolium & 1250 \\
\hline SRS8 & Psychrobacter sp. & FM205059 & 810 & 96 & Rhizosphere of Alyssum serpyllifolium & 1000 \\
\hline SRS15 & Bacillus sp. & FM205060 & 677 & 100 & Rhizosphere of Alyssum serpyllifolium & 1000 \\
\hline SRI2 & Pseudomonas sp. & FM205061 & 511 & 87 & Rhizosphere of Astragalus incanus & 750 \\
\hline SRI4 & Bacillus sp. & FM205062 & 786 & 99 & Rhizosphere of Astragalus incanus & 750 \\
\hline SRI11 & Bacillus sp. & FM205063 & 685 & 99 & Rhizosphere of Astragalus incanus & 750 \\
\hline SRI14 & Bacillus sp. & FM205064 & 858 & 94 & Rhizosphere of Astragalus incanus & 750 \\
\hline
\end{tabular}

a Similarity is at the nucleotide level.

pollutants as they have adapted to such environments (Pal et al., 2005). Partial sequences of $16 \mathrm{~S}$ rDNA of Ni mobilizing strains obtained were matched against nucleotide sequences present in GenBank using the basic local alignment search tool program. The strains SN3, SN9, SRS5, SRS15, SRI4, SRI11 and SRI14 were close to the members of the genus Bacillus. Strain SRS8 showed high similarity with Psychrobacter sp. as did SRI2 with Pseudomonas sp. The sequences were deposited at GenBank (Table 1). Further studies on the characterization of $\mathrm{Ni}$ mobilizing strains at the species level are under progress.

\subsection{Plant growth-promoting features of Ni mobilizing bacteria}

The importance of soil bacteria in heavy metal mobilization and their ability to promote the host plant growth in a metal-contaminated environment make them the preferred choice for the phytoremediation studies. In addition to metal mobilization, certain soil bacteria could exert their beneficial effects on host plant by several possible mechanisms. The mechanisms include: synthesis of ACC deaminase which can hydrolyze ACC (the immediate precursor of the plant hormone ethylene) (Honma and Shimomura, 1978; Adams and Yang, 1979); production of phytohormones, which can enhance the growth of plants (Xie et al., 1996); synthesis of siderophore, which can solubilize and sequester iron from the soil (Burd et al., 2000); and solubilization of phosphorus (Zaidi et al., 2006). Hence, the plant growth-promoting characteristics of $\mathrm{Ni}$ mobilizing strains were further investigated in detail.

The ACC deaminase activity of Ni mobilizing strains was determined by estimating the amount of $\alpha$-KB generated by the enzymatic hydrolysis of ACC. Among the nine strains tested, SN9, SRI2, SRI4, SRI11 and SRI14 grew in Dworkin and Foster minimal salt medium (Dworkin and Foster, 1958) with ACC as the sole source of nitrogen (data not shown). However, strain SRI2 recorded the highest ACC deaminase activity followed by SRI4 (Table 2). The role of ACC deaminase in decreasing ethylene levels by the enzy- matic hydrolysis of ACC into $\alpha-\mathrm{KB}$ and ammonia has been presented as one of the major mechanisms of PGPB in promoting root and plant growth under metal stress condition (Glick et al., 1998). Further screening on the production of IAA by Ni mobilizing bacteria indicated that all strains utilized L-tryptophan as a precursor for growth and IAA production. However, strain SRS8 produced the highest amount, $110 \mathrm{mg} \mathrm{L}^{-1}$ of IAA, whereas SN3 produced only $14 \mathrm{mg} \mathrm{L}^{-1}$ of IAA (Table 2). Generally the PGPB have been reported to influence plant growth by contributing to the host plant's endogenous pool of phytohormones, such as IAA. A low level of IAA produced by $\mathrm{PGPB}$ promotes primary root elongation whereas a high level of IAA stimulates lateral and adventitious root formation but inhibit primary root growth (Xie et al., 1996). In addition to IAA production, the phosphate solubilization by PGPB is believed to play an important role in plant-bacterial interactions and plant growth in metal-contaminated soils (Zaidi et al., 2006). In the present study, all nine strains showed the phosphate solubilizing ability by utilizing the insoluble tricalcium phosphate in modified Pikovskayas medium. However, maximum solubilization of phosphate was recorded in the strains SRS8 $\left(126 \mathrm{mg} \mathrm{L}^{-1}\right)$ and SRI14 (124 $\mathrm{mg} \mathrm{L}^{-1}$ ) (Table 2).

Siderophores are another important metabolite released by the plant growth-promoting rhizobacteria that indirectly alleviate heavy metal toxicity by increasing the supply of iron to the plant (Burd et al., 2000). In the present study, production of siderophores by serpentine isolates was determined using CAS assay (Schwyn and Neilands, 1987). All the strains, except strain SRS5 displayed a positive siderophore activity, as indicated by the development of orange-colored zone on CAS agar plates, after $5 \mathrm{~d}$ of growth. Furthermore, the production of catechol and hydroxamate siderophores was also determined. The maximum production of catechol siderophore was recorded in the strains SN9, SRS8 and SRI2 (Table 2). Similarly, the strain SN9 recorded maximum production of hydroxamate siderophores followed by SRI2. Crowley et al. (1988) previously reported the existence of a siderophore-

Table 2

Plant growth-promoting features of Ni mobilizing bacterial strains.

\begin{tabular}{|c|c|c|c|c|c|c|}
\hline \multirow[t]{2}{*}{ Strain } & \multirow[t]{2}{*}{ ACC deaminase $\left(\mu \mathrm{m} \alpha-\mathrm{KB} \mathrm{mg}^{-1} \mathrm{~h}^{-1}\right)$} & \multirow[t]{2}{*}{ Phosphate solubilization $\left(\mathrm{mg} \mathrm{L}^{-1}\right)$} & \multirow[t]{2}{*}{ IAA synthesis $\left(\mathrm{mg} \mathrm{L}^{-1}\right)$} & \multicolumn{3}{|c|}{ Siderophore production } \\
\hline & & & & CAS assay $(\mathrm{cm})$ & Catechol $\left(\mathrm{mg} \mathrm{L}^{-1}\right)$ & Hydroxamate ( $\mathrm{mg} \mathrm{L}^{-1}$ ) \\
\hline SN3 & nd & $114 \pm 4^{\mathrm{c}}$ & $14 \pm 1^{\mathrm{e}}$ & $1.9 \pm 0.1^{b}$ & $53 \pm 14^{h}$ & $19 \pm 1^{\mathrm{e}}$ \\
\hline SN9 & $19 \pm 2^{c}$ & $101 \pm 3^{d}$ & $72 \pm 1^{\mathrm{d}}$ & $2.3 \pm 0.1^{\mathrm{a}}$ & $1081 \pm 47^{\mathrm{a}}$ & $92 \pm 3^{a}$ \\
\hline SRS5 & nd & $109 \pm 2^{c}$ & $21 \pm 0^{g}$ & nd & nd & nd \\
\hline SRS8 & nd & $126 \pm 2^{\mathrm{a}}$ & $111 \pm 1^{\mathrm{a}}$ & $2.0 \pm 0.1^{\mathrm{ab}}$ & $899 \pm 30^{b}$ & $28 \pm 2^{\mathrm{d}}$ \\
\hline SRS15 & nd & $111 \pm 1^{\mathrm{c}}$ & $84 \pm 3^{b}$ & $1.9 \pm 0.1^{b}$ & $103 \pm 15^{g}$ & $22 \pm 1^{e}$ \\
\hline SRI2 & $73 \pm 3^{a}$ & $119 \pm 3^{b}$ & $61 \pm 1^{\mathrm{f}}$ & $2.1 \pm 0.1^{\mathrm{ab}}$ & $615 \pm 28^{c}$ & $59 \pm 2^{\mathrm{b}}$ \\
\hline SRI4 & $26 \pm 1^{b}$ & $119 \pm 4^{b}$ & $68 \pm 1^{e}$ & $2.2 \pm 0.2^{\mathrm{a}}$ & $435 \pm 21^{\mathrm{e}}$ & $50 \pm 8^{c}$ \\
\hline SRI11 & $16 \pm 1^{\mathrm{c}}$ & $123 \pm 2^{\mathrm{ab}}$ & $77 \pm 3^{c}$ & $2.1 \pm 0.1^{\mathrm{ab}}$ & $528 \pm 16^{d}$ & $53 \pm 1^{c}$ \\
\hline SRI14 & $11 \pm 2^{d}$ & $125 \pm 2^{\mathrm{a}}$ & $20 \pm 1^{g}$ & $2.1 \pm 0.3^{\mathrm{ab}}$ & $228 \pm 24^{f}$ & $31 \pm 2^{d}$ \\
\hline
\end{tabular}

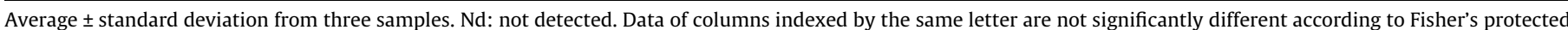
LSD test $(p<0.05)$. 
mediated iron-transport system in oats and suggested that siderophores produced by rhizosphere microorganisms can supply iron to plants that have mechanisms for using these compounds under iron-limited conditions.

The production of ACC deaminase, IAA, siderophores and solubilization of phosphate by $\mathrm{Ni}$ mobilizing bacteria indicate their inherent plant growth-promoting potential. Considering such potential, the efficiency of Ni mobilizing PGPB on plant growth and $\mathrm{Ni}$ uptake by Brassica species was tested in Ni contaminated soils.

\subsection{Influence of Ni mobilizing PGPB on plant growth and Ni uptake}

Nickel in excessive concentration disturbs photosynthetic electron transport (Mohanty et al., 1989) as well as inhibits $\mathrm{CO}_{2}$ assimilation and stomatal conductance (Sheoran et al., 1990). In our experiment, the non-inoculated plants exposed to $450 \mathrm{mg} \mathrm{Ni} \mathrm{kg}{ }^{-1}$ demonstrated a significant $(p<0.05)$ inhibition in plant growth. It has earlier been reported that increasing $\mathrm{Ni}$ supply resulted in decreased plant biomass indicating the alterations of physiology and metabolism of test plants (Zaidi et al., 2006). B. juncea inoculated with Ni mobilizing strains exhibited an increase in plant fresh and dry weight in the presence of $\mathrm{Ni}$. Among nine strains, the three best performers with respect to plant growth promotion potential were recorded as SRI2 $>$ SRS8 $>$ SN9. Similarly, B. oxyrrhina inoculated with $\mathrm{Ni}$ mobilizing strains exhibited an increase in plant growth. On the basis of $B$. oxyrrhina growth promotion, the bacterial strains may be arranged in the order as: SRI2 > SN9 $>$ SRS8. The results obtained here clearly indicate that inoculation with $\mathrm{Ni}$ mobilizing PGPB especially SRI2, SRS8 and SN9 was highly efficient at protecting the plants from growth inhibition caused by toxic soil Ni concentrations.

The PGPB inoculation has been reported to have a positive influence on various plant growth parameters, including root and shoot length, fresh and dry biomass (Zaidi et al., 2006). ACC deaminase producing bacteria have been reported to prevent the inhibition of root elongation by decreasing the level of growth-limiting ethylene through hydrolytic cleavage (deaminase activity) of the ethylene biosynthesis precursor ACC (Adams and Yang, 1979; Glick et al., 1998). However, in our study the significant increase in the fresh and dry biomass of the crop plants treated with ACC deaminase-negative strain SRS8 (Table 3) suggests that the effects of other plant growth-promoting features such as the production of IAA, siderophore and solubilization of phosphate should also be considered in addition to ACC deaminase activity. In general, the

Table 3

Influence of Ni mobilizing bacteria on the fresh weight and dry weight of Brassica species.

\begin{tabular}{|c|c|c|c|c|}
\hline \multirow[t]{2}{*}{ Bacterial strain } & \multicolumn{2}{|l|}{ B. juncea } & \multicolumn{2}{|l|}{ B. oxyrrhina } \\
\hline & $\begin{array}{l}\text { Fresh weight } \\
\left(\mathrm{mg} \mathrm{plant}^{-1}\right)\end{array}$ & $\begin{array}{l}\text { Dry weight } \\
\left(\mathrm{mg} \mathrm{plant}^{-1}\right)\end{array}$ & $\begin{array}{l}\text { Fresh weight } \\
\left(\mathrm{mg} \mathrm{plant}^{-1}\right)\end{array}$ & $\begin{array}{l}\text { Dry weight } \\
\left(\mathrm{mg} \mathrm{plant}^{-1}\right)\end{array}$ \\
\hline Control & $291 \pm 1^{d}$ & $16.5 \pm 0.2^{c}$ & $189 \pm 6^{b}$ & $8.5 \pm 0.4^{b}$ \\
\hline $\mathrm{Ni}$ & $260 \pm 1^{e}$ & $14.9 \pm 0.3^{\mathrm{d}}$ & $153 \pm 1^{e}$ & $8.0 \pm 0.1^{c}$ \\
\hline SN3 & $270 \pm 2^{\mathrm{e}}$ & $15.1 \pm 0.2^{\mathrm{d}}$ & $164 \pm 2^{\mathrm{d}}$ & $8.4 \pm 0.2^{b}$ \\
\hline SN9 & $312 \pm 1^{b}$ & $17.1 \pm 0.2^{\mathrm{a}}$ & $197 \pm 1^{\mathrm{a}}$ & $9.5 \pm 0.3^{\mathrm{a}}$ \\
\hline SRS1 & $284 \pm 2^{\mathrm{d}}$ & $16.1 \pm 0.3^{b, c}$ & $176 \pm 1^{\mathrm{c}}$ & $8.4 \pm 0.8^{b}$ \\
\hline SRS5 & $265 \pm 4^{\mathrm{e}}$ & $15.5 \pm 0.2^{c}$ & $160 \pm 5^{d}$ & $8.5 \pm 0.2^{b}$ \\
\hline SRS8 & $321 \pm 2^{a}$ & $17.2 \pm 0.4^{\mathrm{a}}$ & $194 \pm 2^{\mathrm{a}}$ & $9.4 \pm 0.1^{\mathrm{a}}$ \\
\hline SRS15 & $268 \pm 5^{\mathrm{e}}$ & $15.9 \pm 0.6^{c}$ & $162 \pm 3^{d}$ & $8.6 \pm 0.2^{b}$ \\
\hline SRI2 & $322 \pm 6^{a}$ & $17.3 \pm 0.4^{\mathrm{a}}$ & $199 \pm 1^{\mathrm{a}}$ & $9.6 \pm 0.2^{\mathrm{a}}$ \\
\hline SRI4 & $295 \pm 4^{c}$ & $17.2 \pm 0.4^{\mathrm{a}}$ & $191 \pm 1^{b}$ & $9.3 \pm 0.1^{\mathrm{a}}$ \\
\hline SRI11 & $294 \pm 3^{c}$ & $17.0 \pm 0.7^{\mathrm{a}}$ & $189 \pm 3^{b}$ & $9.2 \pm 0.1^{a}$ \\
\hline SRI14 & $285 \pm 4^{\mathrm{d}}$ & $16.6 \pm 0.5^{\mathrm{b}}$ & $176 \pm 8^{c}$ & $8.7 \pm 0.2^{b}$ \\
\hline
\end{tabular}

Average \pm standard deviation from three samples. nd: not detected. Data of columns indexed by the same letter are not significantly different according to Fisher's protected LSD test $(p<0.05)$. reduction of plant growth in metal-contaminated soil is often associated with iron deficiency and reduced uptake of phosphate (Halstead et al., 1969; Burd et al., 2000). Inoculation of phosphate solubilizing and siderophore producing PGPB might have helped plant root proliferation and enhanced the uptake of soil minerals such as $\mathrm{P}$ and Fe by the host plant (Braud et al., 2006; Zaidi et al., 2006). Further, IAA produced by PGPB promotes the root growth by directly stimulating plant cell elongation or cell division (Glick et al., 1998). In addition, earlier studies have reported that the plant growth under adverse environmental condition is correlated with population density of beneficial bacteria in the rhizosphere or roots (Ashraf et al., 2004). Hence, in this study, the population densities of Ni mobilizing PGPB in the rhizosphere of $B$. juncea and $B$. oxyrrhina were analyzed. In general, the Ni mobilizing PGPB strains colonized comparatively better on the B. juncea rhizosphere soil than on the B. oxyrrhina rhizosphere soil (Fig. 2). The data indicate that colonization efficiency of PGPB may depend on specific interactions between bacterial species and host plants. Though the strains SN9 and SRS8 were isolated from the non-rhizosphere soil and the rhizosphere soil of $A$. serpyllifolium, respectively, they showed high level of colonization on the rhizosphere of both $B$. juncea and B. oxyrrhina. The observations indicate that there was a significant relationship between the plant growth and the population density of added PGPB on the rhizosphere. In general, the potential of root colonization by inoculated PGPB depends on various parameters such as bacterial traits, root exudates, biotic and abiotic factors (Benizri et al., 2001). Hence, the interactions between root exudates and PGPB, and their influence on biochemical changes in the rhizosphere need to be investigated further to know the factors involved in root colonization by both the strains of this study. The findings, therefore, suggest successful colonization and subsequent plant growth-promoting potentiality of SN9 and SRS8 in both of the plants (Fig. 2).

The accumulation and distribution of metals in the plant tissue are important aspects to evaluate the role of plants in remediation of contaminated sites (Kumar et al., 1995). In the present study, we assessed whether inoculation with $\mathrm{Ni}$ mobilizing PGPB strains affected the uptake of $\mathrm{Ni}$ by $B$. juncea and $B$. oxyrrhina plants (Fig. 3). In general, B. oxyrrhina accumulated more $\mathrm{Ni}$ in both the shoot and root tissues compared with $B$. juncea. Further, the inoculation of Ni mobilizing strains significantly increased the accumu-

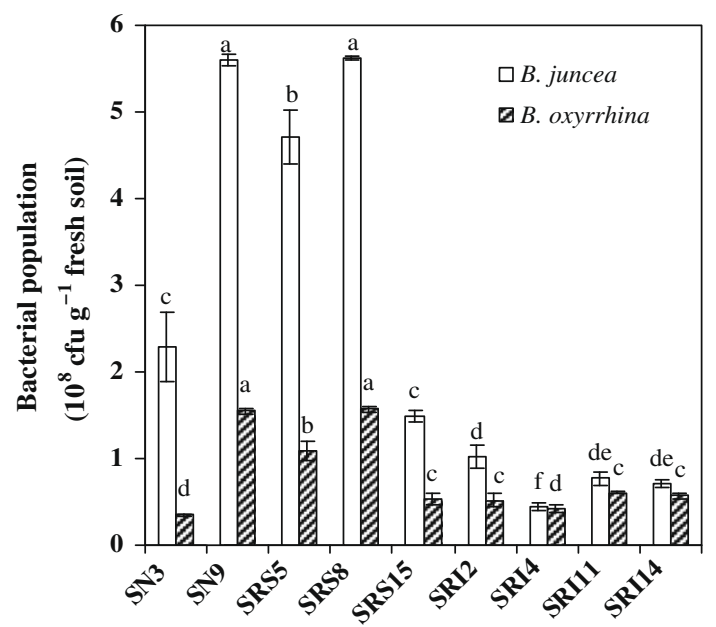

Ni mobilizing bacterial strains

Fig. 2. Colonization potential of Ni mobilizing bacterial strains in rhizosphere soil of $B$. juncea and B. oxyrrhina. Each value is the mean of triplicates. Error bars represent standard deviation. Data of columns indexed by the same letter are not significantly different according to Fisher's protected LSD test $(p<0.05)$. 


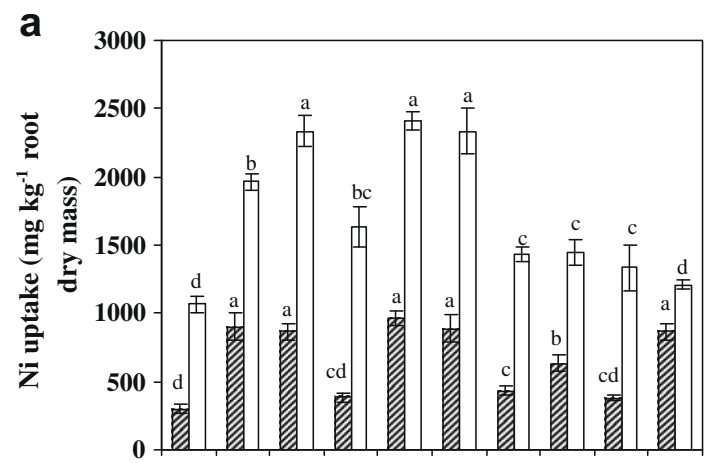

b

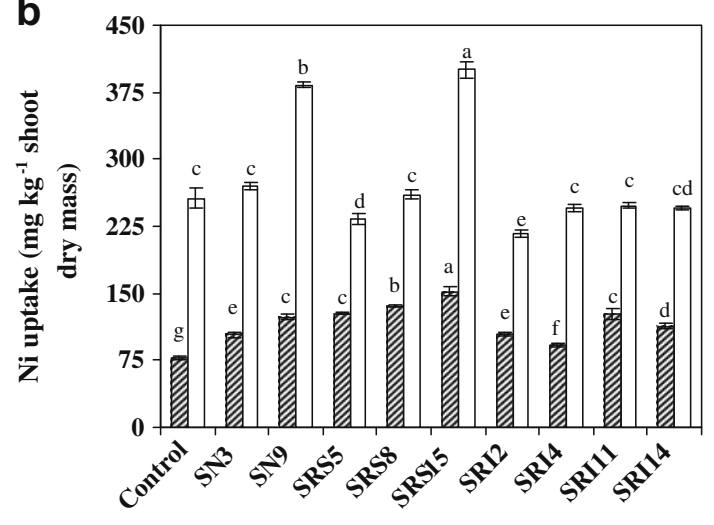

Ni mobilizing bacterial strains

B. juncea $\square$ B. oxyrrhina

Fig. 3. Ni concentration $\left(\mathrm{mg} \mathrm{kg}^{-1}\right)$ in root (a) and shoot system (b) of B. juncea and $B$. oxyrrhina. Each value is the mean of triplicates. Error bars represent standard deviation. Data of columns indexed by the same letter are not significantly different according to Fisher's protected LSD test $(p<0.05)$.

lation of $\mathrm{Ni}$ in the root tissues of both $B$. juncea and B. oxyrrhina compared with respective non-inoculated controls (Fig. 3a). For instance, strain SRS8 increased the Ni concentration in the root tissues of B. juncea and B. oxyrrhina by $222 \%$ and $126 \%$, respectively. In contrast to the present observation, Vivas et al. (2006) reported that inoculation with PGPB Brevibacillus sp. reduced Zn uptake in Trifolium repens plants. Previously, B. juncea grown in nickel amended soil were found to be able to accumulate significant amount of nickel in their shoots (Kumar et al., 1995). However, in the work reported here, it was found that the inoculated and non-inoculated root tissues accumulated considerably more $\mathrm{Ni}$ as compared to the respective shoot tissues. This can be attributed to poor translocation of nickel from root to shoot system (Burd et al., 2000). Further, the inoculation of bacterial strains did not greatly influence the accumulation of $\mathrm{Ni}$ in shoot tissues as compared to the root tissues of respective plants. However, the strains SN9 and SRS15 significantly increased the accumulation of $\mathrm{Ni}$ in the shoot tissues of both $B$. juncea and $B$. oxyrrhina compared with respective non-inoculated controls (Fig. 3b). For instance, strain SN9 increased the Ni concentration in the shoot tissues of $B$. juncea and B. oxyrrhina by $58 \%$ and $49 \%$, respectively. Studies have evidenced that heavy metal resistant bacteria can enhance metal uptake by hyperaccumulator plants (Whiting et al., 2001) as has shown in our experiment that the Ni uptake by $B$. juncea and $B$. oxyrrhina was enhanced by the Ni resistant PGPB SN9 and SRS8.

In order to confirm the correlation between bacterial Ni mobilization in soil and total $\mathrm{Ni}$ accumulation in plants, we performed a regression analysis of bacterial Ni mobilization and the Ni accumulation in plants that had been inoculated with the corresponding isolate. A positive correlation was observed between the bacterial
$\mathrm{Ni}$ mobilization in soil and the total $\mathrm{Ni}$ uptake in both $B$. juncea $\left(R^{2}=0.390, p=0.022\right)$ and $B$. oxyrrhina $\left(R^{2}=0.471, p=0.007\right)$ (Fig. 4). The Ni mobilizing PGPB, SRS8 and SRS15 had maximum $\mathrm{Ni}$ mobilization potential and they were also found to be most effective in promoting $\mathrm{Ni}$ accumulation in both $B$. juncea and $B$. oxyrrhina. Our result indicates that Ni mobilizing PGPB facilitated the release of $\mathrm{Ni}$ from the non-soluble phases in the soil, thus enhancing the availability of $\mathrm{Ni}$ to plants. These effects of inoculation were reported also by Rajkumar and Freitas (2008), who found that the addition of Pseudomonas jessenii to surface sterilized root of Ricinus communis in autoclaved soil increased $\mathrm{Ni}, \mathrm{Cu}$ and $\mathrm{Zn}$ concentrations in root tissues compared with non-inoculated controls. Possible explanations include soil acidification, release of siderophores and phosphate solubilization (Abou-Shanab et al., 2005; Zaidi et al., 2006). Although the microbial activity strongly influences metal speciation and transport in environment, further studies including e.g. detailed chemical (metabolite) and microbial analysis in the rhizosphere are required to better understand the interactions between microorganisms and heavy metal accumulating plants and to elucidate the mechanisms how bacteria can promote heavy metal accumulation and translocation in plants.
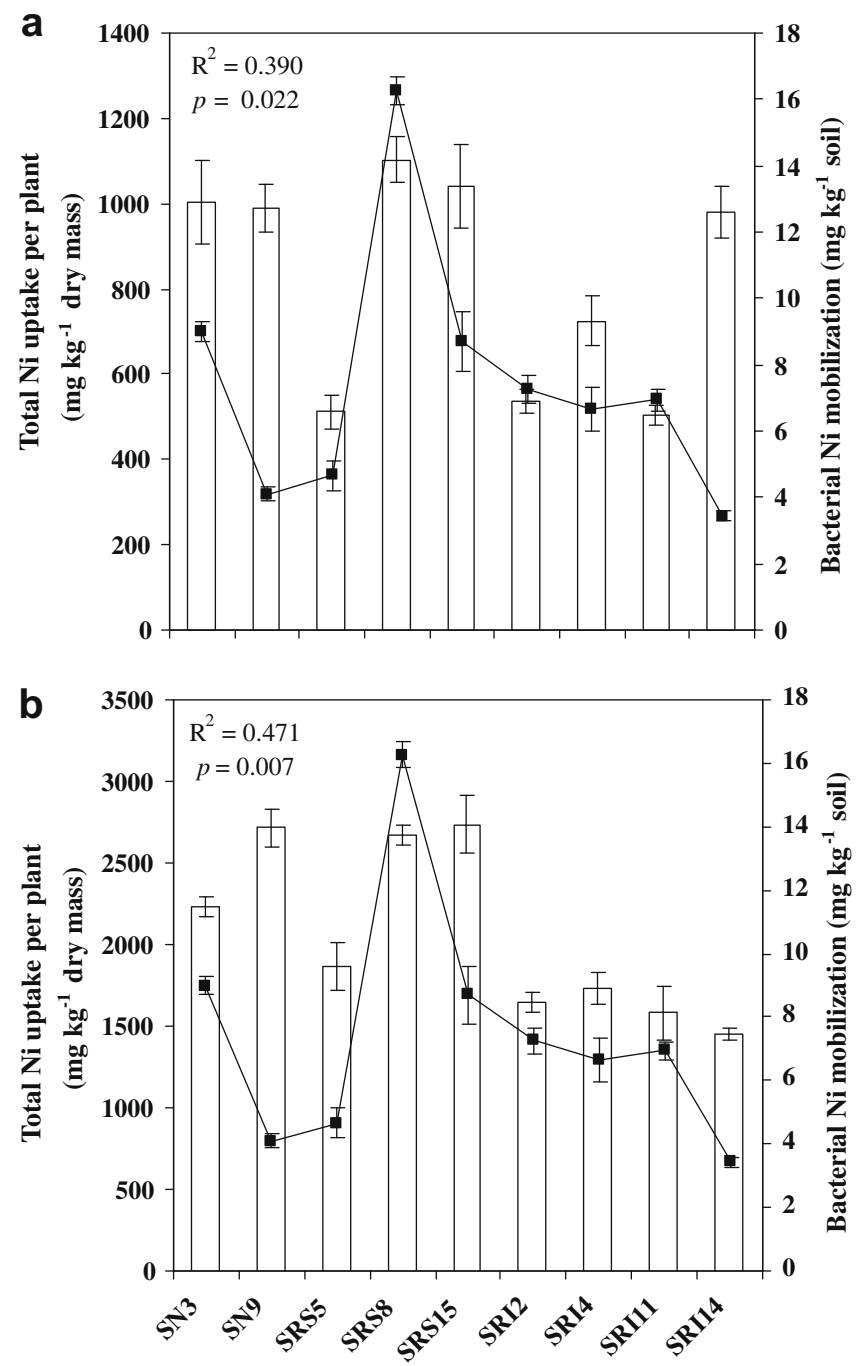

Ni mobilizing bacterial strains

$\square$ Ni uptake $\rightarrow-$ Ni mobilization

Fig. 4. (a) Regression of bacterial Ni mobilization in soil and the total Ni uptake in $B$. juncea inoculated with bacterial isolates. (b) Regression of bacterial Ni mobilization in soil and the total Ni uptake in B. oxyrrhina inoculated with bacterial isolates. 


\section{Conclusions}

The results obtained here indicate that inoculation of Ni mobilizing PGPB, Pseudomonas sp. SRI2, Psychrobacter sp. SRS8 and Bacillus sp. SN9 seemed to be very effective in protecting plants from growth inhibition caused by $\mathrm{Ni}$. As successful bioinoculant for microbial-assisted phytoremediation, the microorganisms must be able to promote plant growth and heavy metal uptake. In the present study, though the strains SRI2 and SRS8 significantly increased the growth of B. juncea and B. oxyrrhina in Ni contaminated soils, they did not greatly influence the quantity of accumulation of $\mathrm{Ni}$ in shoot tissues of B. oxyrrhina plants. However, the strain SN9 not only significantly increased the $\mathrm{Ni}$ concentration in the root and shoot tissues of both B. juncea and B. oxyrrhina, but also promoted the plant growth against the toxic effects of $\mathrm{Ni}$ in soils. The increase in plant growth caused by strain SN9 may be attributed to the production of IAA, siderophore and solubilization of phosphate. The findings, therefore, revealed that inoculation of $\mathrm{Ni}$ mobilizing PGPB strain SN9 increases the efficiency of phytoextraction directly by enhancing $\mathrm{Ni}$ accumulation in plant tissues and indirectly by promoting the shoot and root biomass of $B$. juncea and $B$. oxyrrhina. Due to multifarious properties expressed by the Ni mobilizing PGPB in this study, the strain SN9 could therefore, be used as bioinoculant to increase the phytoremediation potential of hyperaccumulators in soils contaminated with nickel. However, it should also be mentioned that these experiments were performed under laboratory conditions and in a sterile environment without any interference of competing microorganisms that are present in soil. Further works including the population dynamics and activity of inoculated bacteria in their host plants, the mechanisms involved in Ni mobilization by bacteria, and the basic mechanisms of plant-microbe interactions in the rhizosphere are required to implement these microbial-assisted phytoremediation in field level.

\section{References}

Abou-Shanab, R.A., Angle, J.S., Delorme, T.A., Chaney, R.L., van Berkum, P., Moawad, H., Ghanem, K., Ghozlan, H.A., 2003. Rhizobacterial effects on nickel extraction from soil and uptake by Alyssum murale. New Phytol. 158, 219-224.

Abou-Shanab, R.A., Ghozlan, H., Ghanem, K., Moawad, H., 2005. Behaviour of bacterial populations isolated from rhizosphere of Diplachne fusca dominant in industrial sites. World J. Microb. Biotechnol. 21, 1095-1101.

Adams, D.O., Yang, S.F., 1979. Ethylene biosynthesis: identification of 1aminocyclopropane-1-carboxylic acid as an intermediate in the conversion of methionine to ethylene. Proc. Natl. Acad. Sci. USA 76, 170-174.

Altschul, S.F., Madden, T.L., Schaffer, A.A., Zhang, J., Zhang, Z., Miller, W., Lipman, D.J., 1997. Gapped BLAST and PSIBLAST: a new generation of protein database search programs. Nucleic Acid Res. 25, 3389-3402.

Arnow, E., 1937. Colorimetric determination of the components of 3,4dihydroxyphenylalanine-tyrosine mixtures. J. Biol. Chem. 118, 531-537.

Ashraf, M., Hasnain, S., Berge, O., Mahmood, T., 2004. Inoculating wheat seedlings with exopolysaccharide-producing bacteria restricts sodium uptake and stimulates plant growth under salt stress. Biol. Fert. Soils 40, 157-162.

Atkin, C.L., Neilands, J.B., Phaff, H.J., 1970. Rhodotorulic acid from species of Leucosporidium, Rhodosporidium, Rhodotorula, Sporidiobolus, and Sporobolomyces, and a new alanine-containing ferrichrome from Cryptococcus melibiosum. J. Bacteriol. 103, 722-733.

Barber, D.A., Lee, R.B., 1974. The effect of microorganisms on the absorption of manganese by plants. New Phytol. 43, 97-106.

Benizri, E., Baudoin, E., Guckert, A., 2001. Root colonization by inoculated plant growth-promoting rhizobacteria. Biocontrol Sci. Technol. 11, 557-574.

Branco, R., Chung, A.P., Verissimo, A., Morais, P.V., 2005. Impact of chromiumcontaminated wastewaters on the microbial community of a river. FEMS Microb. Ecol. 54, 35-46.

Braud, A., Jézéquel, K., Vieille, E., Tritter, A., Lebeau, T., 2006. Changes in extractability of $\mathrm{Cr}$ and $\mathrm{Pb}$ in a polycontaminated soil after bioaugmentation with microbial producers of biosurfactants, organic acids and siderophores. Water Air Soil Poll. 6, 3-4.

Bric, J.M., Bostock, R.M., Silversone, S.E., 1991. Rapid in situ assay for indole acetic acid production by bacteria immobilization on a nitrocellulose membrane. Appl. Environ. Microb. 57, 535-538.
Brooks, R.R., 1987. Serpentine and Its Vegetation. Dioscorides Press, Portland, OR. pp. 322.

Burd, G.I., Dixon, D.G., Glick, B.R., 2000. Plant growth-promoting bacteria that decrease heavy metal toxicity in plants. Can. J. Microb. 46, 237-245.

Chen, B.D., Shen, H., Li, X.L., Feng, G., Christie, P., 2004. Effects of EDTA application and arbuscular mycorrhizal colonization on growth and zinc uptake by maize (Zea mays L.) in soil experimentally contaminated with zinc. Plant Soil 261, 219-229.

Crowley, D.E., Reid, C.P.P., Szaniszlo, P.J., 1988. Utilization of microbial siderophores in iron acquisition by oat. Plant Physiol. 87, 680-685.

Crowley, D.E., Wang, Y., Reid, C.P.P., Szaniszlo, P.J., 1991. Mechanisms of Fe acquisition from siderophores by microorganisms and plants. In: Chen, Y., Hadar, Y. (Eds.), Iron Nutrition and Interactions in Plants. Kluwer Academic Publishers, Dordrecht, The Netherlands, pp. 213-232.

Dunbar, J., Takala, S., Barns, S.M., Davis, J.A., Kuske, C.R., 1999. Levels of bacterial community diversity in four arid soils compared by cultivation and 16S rRNA gene cloning. Appl. Environ. Microb. 65, 1662-1669.

Dworkin, M., Foster, J., 1958. Experiments with some microorganisms which utilize ethane and hydrogen. J. Bacteriol. 75, 592-601.

Fiske, C.H., Subbarow, Y., 1925. A colorimetric determination of phosphorus. J. Biol. Chem. 66, 375-400.

Freitas, H., Prasad, M.N.V., Pratas, J., 2004. Analysis of serpentinophytes from northeast of Portugal for trace metal accumulation relevance to the management of mine environment. Chemosphere 54, 1625-1642.

Glick, B.R., Penrose, D.M., Li, J., 1998. A model for the lowering of plant ethylene concentrations by plant growth promoting bacteria. J. Theor. Biol. 190, 63-68.

Halstead, R.L., Finn, B.J., MacLean, A.J., 1969. Extractability of nickel added to soils and its concentration in plants. Can. J. Soil Sci. 49, 335-342.

Holden, T., 1989. How to Select Hazardous Waste Treatment Technologies for Soils and Sludges: Alternative Innovative and Emerging Technologies. Noyes Data Corporation, Park Ridge, NJ.

Honma, M., Shimomura, T., 1978. Metabolism of 1-aminocyclopropane-1carboxylic acid. Agri. Biol. Chem. Tokyo 42, 1825-1831.

Idris, R., Trifonova, R., Puschenreiter, M., Wenzel, W.W., Sessitsch, A., 2004. Bacterial communities associated with flowering plants of the Ni hyperaccumulator Thaspi goesingense. Appl. Environ. Microb. 70, 2667-2677.

Kayser, A., Wenger, K., Keller, A., Attinger, W., Felix, H.R., Gupta, S.K., Schulin, R., 2000. Enhancement of phytoextraction of $\mathrm{Zn}, \mathrm{Cd}$, and $\mathrm{Cu}$ from calcareous soil: the use of NTA and sulfur amendments. Environ. Sci. Technol. 34, 1778-1783.

Kumar, P.B.A.N., Dushenkov, V., Motto, H., Raskin, I., 1995. Phytoextraction: the use of plants to remove heavy metals. Environ. Sci. Technol. 29, 1232-1238.

McGrath, S.P., Zhao, F.J., 2003. Phytoextraction of metals and metalloids from contaminated soils. Curr. Opin. Biotechnol. 14, 277-282.

Mohanty, N., Vass, J., Demeter, S., 1989. Impairment of photosystem 2 activity at the level secondary quinone electron acceptor in chloroplasts treated with cobalt, nickel and zinc ions. Physiol. Plantarum 76, 389-390.

Pal, A., Dutta, S., Mukherjee, P.K., Paul, A.K., 2005. Occurrence of heavy metalresistance in microflora from serpentine soil of Andaman. J. Basic Microb. 45, 207-218.

Puschenreiter, M., Stoger, G., Lombi, E., Horak, O., Wenzel, W.W., 2001. Phytoextraction of heavy metal contaminated soils with Thlaspi goesingense and Amaranthus hybridus: rhizosphere manipulation using EDTA and ammonium sulphate. J. Plant Nutr. Soil Sci. 164, 615-621.

Rajkumar, M. Freitas, $H$., 2008. Influence of metal resistant-plant growthpromoting bacteria on the growth of Ricinus communis in soil contaminated with heavy metals. Chemosphere 71, 834-842.

Salt, D.E., Prince, R.C., Pickering, I.J., Raskin, I., 1995. Mechanisms of cadmium mobility and accumulation in Indian mustard. Plant Physiol. 109, 1427-1433.

Sambrook, J., Fritsch, E.F., Maniatis, T., 1989. Molecular Cloning: A Laboratory Manual, second ed. Cold Spring Harbor Laboratory Press, Cold Spring Harbor, NY.

Schwyn, B., Neilands, J.B., 1987. Universal chemical assay for the detection and determination of siderophores. Anal. Biochem. 160, 47-56.

Sheoran, I.S., Singal, H.R., Singh, R., 1990. Effect of cadmium and nickel on photosynthesis and the enzymes of the photosynthetic carbon reduction cycle in pigeonpea (Cajanus cajan L.). Photosynth. Res. 23, 345-351.

Sundara-Rao, W.V.B., Sinha, M.K., 1963. Phosphate dissolving microorganisms in the soil and rhizosphere. Indian J. Agr. Sci. 33, 272-278.

Vivas, A., Biro, B., Ruíz-Lozanoa, J.M., Azcon, R., 2006. Two bacterial strains isolated from a $\mathrm{Zn}$-polluted soil enhance plant growth and mycorrhizal efficiency under Zn toxicity. Chemosphere 52, 1523-1533.

Whiting, S.N., De-Souza, M.P., Terry, N., 2001. Rhizosphere bacteria mobilize Zn for hyperaccumulation by Thlaspi caerulescens. Environ. Sci. Technol. 15, 31443150.

Xie, H., Pasternak, J.J., Glick, B.R., 1996. Isolation and characterization of mutants of the plant growth-promoting rhizobacterium Pseudomonas putida GR12-2 that overproduce indoleacetic acid. Curr. Microb. 32, 67-71.

Zaidi, S., Usmani, S., Singh, B.R., Musarrat, J., 2006. Significance of Bacillus subtilis strain SJ-101 as a bioinoculant for concurrent plant growth promotion and nickel accumulation in Brassica juncea. Chemosphere 64, 991-997. 